\title{
Honesty: The Stinging Fly on the Rump of Free State Respectability
}

\author{
Anthony Keating \\ Edge Hill University, UK \\ keatingt@edgehill.ac.uk
}

\begin{abstract}
Copyright (c) 2017 by Anthony Keating. This text may be archived and redistributed both in electronic form and in hard copy, provided that the author and journal are properly cited and no fee is charged for access.
\end{abstract}

\begin{abstract}
This essay will examine the exposé of the realities regarding poverty, immorality and sexual crime in the Irish Free State by the radical journal Honesty (1925-1931). Honesty was edited by the socialist republican James W. Upton, a man with a longstanding commitment to the rights of women and the poor. Upton was by instinct anti-establishment in an era when the country's religio-political leadership was insecure and keen to manage the Free State's news agenda. Something they attempted in the service of projecting what was viewed as an ideologically acceptable image of life in the Free Sate, to both domestic and foreign audiences. Upton viewed this policy as a manifestation of the social and political cant favoured by the Free State's leadership, which was aided and abetted by, and gave succour to, the hypocrisy of wider bourgeois Free State society. A coalition of forces, Upton reasoned, that damaged the interests of the most vulnerable sections of Irish society, in particular, the nation's women and children living on or below the breadline. However, notwithstanding it radicalism and reputation in the Free State, Honesty has been largely lost to the history of Irish journalism.
\end{abstract}

Key Words. Irish Free State, Prostitution, Journalism, Sexual Crime, Women, Illegitimacy, Child Abuse, Poverty.

Resumen. En este trabajo se examina cómo la revista Honesty (1925-1931) desveló las verdades incómodas sobre pobreza, inmoralidad y delitos sexuales en los primeros años del Estado Libre de Irlanda. El editor de la revista, James W. Upton, era un republicano de ideología socialista en cuya trayectoria destacaba un firme compromiso con los derechos de las mujeres y de los menos favorecidos. Upton era por instinto antisistema, en una época en la que el liderazgo del país adolecía de serias deficiencias. La clase dirigente mostraba un desmedido interés por controlar las noticias relacionadas con Irlanda y por proyectar, tanto a nivel nacional como internacional, imágenes amables y positivas sobre el nuevo estado. Para Upton, esta actitud no era sino una muestra más de la hipocresía reinante entre las élites del Estado Libre de Irlanda, las cuales encontraban un necesario apoyo entre un amplio sector de la burguesía. Para Upton, esta coalición de fuerzas actuaba en detrimento de los sectores más débiles de la sociedad, especialmente aquellos que vivían por debajo del umbral de la 
pobreza. A pesar de su actitud crítica con el poder y de la importante repercusión que tuvo en su época, Honesty apenas es tenida en cuenta en la historia del periodismo en Irlanda.

Palabras clave. Estado Libre de Irlanda, prostitución, periodismo, delitos sexuales, mujeres, hijos ilegítimos, abusos a menores, pobreza.

On the 28th of February 1925 the journal Honesty. A Weekly Journal of Independent Criticism commenced publishing and was to continue publication until the $28^{\text {th }}$ of February 1931. Edited by the socialist-republican, James W. Upton, the journal claimed lineage from a pre-Easter Rising publication of the same name, which had published from the October of 1915 to the 25 April 1916.

Upton's republican credentials were immaculate. A friend and commrade of many leading republicans of the day, he was in possession of what Eithne MacDermott described as "the ultimate legitimising symbol in the republican gallery of iconography" (1998: 1), having taken part in the Easter Rising of 1916. This afforded Upton with a significant store of social and political capital which he was to deploy in the service of the marginalised, up until the point that Honesty was forced to close. Honesty's closure resulted from the undermining of its readership by his old commrade, Eamon de Valera's Fianna Fáil party machine, when Upton and Honesty were percieved as threatening de Valera's political ambition (Keating 2015: 92).

Upton was born in Waterford in 1872 and came under the influence of the Fenian James O'Connor whilst a student at Mount Sion Christian Brothers school, where he also developed a lifelong passion for Gaelic Games. He cut his journalistic teeth as a cub reporter on the Waterford Star and soon developed a national reputation as a Gaelic Games journalist, under the pen name "Vigilant." Gaelic Games and nationalism for Upton were indivisible, and he comfortably fitted into that cohort of Gaelic games journalists who, W.F. Mandle asserted, were "nationalists unrepentant and unconcealed" (Murphy 2009: 63). Upton, a close friend of Arthur Griffith, ${ }^{1}$ played an important role in organising Sinn Féin, both in Waterford and nationally, providing copy for the Sinn Fein newspaper up until its suppression in 1914. Upton's Sinn Féin activity eventually forced him to resign from his post at the Waterford Star as a result of pressure from pro-British businessmen who threatened to boycott the newspaper if he remained in post. However, he quickly gained employment as editor of the Kilkenny Journal, a moderate nationalist publication which became increasingly radicalised under his editorship, up until his resignation in 1922.

In addition to his work on the Kilkenny Journal, Upton wrote weekly copy for Joseph Stanley's Gaelic Press publication Gaelic Athlete and was a leading light on several "mosquito press"" publications, also produced at Stanley's print works. He edited Scissors and Paste, Honesty and The Spark, under the pseudonyms Ed Dalton and Gilbert Galbraith (Novick 2001: 34), both pen names he resurrected during Honesty's second run. During March 1916, the Gaelic Press' printing presses were seized by the British authorities, however, Stanley and Upton continued their work using a borrowed printing press in the basement of Liberty Hall, under an armed guard provided by the Irish Citizen Army. Subsequently, Upton and Stanley were attached to the General Post Office garrison, the epicentre of the Easter Rising. Under orders from Pádraig Pearse and James Connolly they commandeered a small printing works in Halston Street, from where they printed Pearse's bulletins to the citizens of Dublin (Reilly 2005: 33). Indeed, the last issue of Honesty's original run was produced under the title, Irish War News (Honesty, 10 August 1929), the only publication known to have been printed during the Rising in the area of central Dublin controlled by the rebels. 
Following the Easter Rising, Upton avoided arrest, slipping back to Kilkenny to continue his editorial role and republican agitation, notably using the Kilkenny Journal's presses to publish the short lived yet influential republican journal, The Phoenix. Upton's journalistic contribution to the republican cause was acknowledged in 1936 by J. Bouch of the National Library, who writing in the Irish Press, described Upton as "next to Griffith the most trenchant of republican journalists" (April 15 1936). Upton's career under British rule had been punctuated by a fiercely independent, uncompromising voice, a feature of his journalism that would continue in the Irish Free State (IFS), irrespective of which party was in power.

Honesty's second edition was forthright and uncompromising and by far and away the most socially radical journal published in the IFS, exposing what it viewed as Ireland's sordid underbelly. The journal combined in-house reporting and comment as well as providing opinion pieces, which were frequently printed under pseudonyms. ${ }^{3}$ It is difficult to ascertain how much of the copy that appeared in Honesty was penned directly by Upton, but stylistically several important pieces including those penned by "Special Correspondent," referred to below, indicate this possibility. Additionally, Upton was known throughout his career to be an inveterate user of pen names (Seamus Upton 2014). Whatever the reality of its in-house authorship, Honesty's formula quickly established a healthy nationwide readership and attracted high profile contributors that including, W.T. Cosgrave, President of the Executive Council (Prime Minister) and Eamon de Valera, the leader of Sinn Féin, and latterly Fianna Fáil (Keating 2015: 85).

Notwithstanding this, until recently very few scholars have mentioned Honesty, and then only in passing. For example, the historian of Irish theatre, Joan Fitzpatrick Dean, whilst noting that Sean O' Casey was a regular reader of Honesty, acknowledged its progressiveness in candidly addressing "issues not consonant with the conception of Ireland as a Catholic country." However, Fitzpatrick Dean categorizes Honesty as a "muck racking" publication (Fitzpatrick-Dean 2001: 136). This classification is contested here as a close reading of Honesty demonstrates that, by and large, it avoided the style of scandalous journalism found in the prurient press, instead, focusing on a socially campaigning form of journalism, written for a literate, engaged readership. Its shock value emerged from the reality it portrayed and the socio-political analysis it offered in explanation of issues usually viewed in the IFS as the product of personal depravity, and/or social inadequacy (Ferguson 2007: 136; Crowley and Kitchin 2008: 358). Additionally, Fitzpatrick Dean suggests that many of the concerns covered in Honesty now appear "risible or alarmist," (136) another assertion contested here. Domestic issues covered included political corruption, poor educational opportunities, poverty driving women into prostitution, poor health and housing, unemployment, the maltreatment of children in the care of the state and the plight of unmarried mothers and their children. Honesty's international coverage included critiques of Britain's wider colonial policy, which in common with its domestic coverage were viewed through an anti-capitalist, anti-racist, anti-imperial lens ${ }^{4}$ that anticipated the work of later post-colonial theorists. In this regard Honesty was part of a rich vein of republican journalism offered in a range of mosquito press publications produced in Ireland in the 1920s and 30s (Ní Bheacháin 2007: 258). However, unlike many of these publications Honesty, whilst unhappy with Partition, was not a revolutionary anti-statist publication. Upton, whilst conceiving Honesty as a serious journalistic irritant to the political settlement that created the IFS, believed that it should operate within the political settlement to advocate for the poor and to challenge Partition. The seriousness of Honesty's intent ensured that issues, no matter how scandalous, were explored in a campaigning rather than a titivating style and much of its content has been shown to be neither "risible or alarmist" in the context of the now visible history of the modern Irish State.

There was, however, a less progressive and at times contradictory aspect to the journalism of Honesty, not least its anti-Semitism, a feature that found some traction in Irish 
Republican circles in the period (Keogh 1998: 56). Additionally, homosexuality, dance halls and contraception were castigated in its pages, and, despite its editor's adherence to freedom of journalistic speech and expression, Honesty was largely supportive of literary and advertising censorship of what it viewed as salacious material that was likely to harm public morality.

Notwithstanding this, Honesty and its editor Upton, whilst undoubtedly informed by a number of the prejudices of the age, expressed a liberality of spirit to a wide swath of the marginalized and socially outcast of Irish society. These were individuals who Ferguson has described as being viewed as "moral dirt" for much of Ireland's $20^{\text {th }}$-century history, a labelling which led to their social exclussion and amplified their vulnarability (Ferguson 2007: 136). The compassion and analysis of much of Honesty's content, particularly regarding women working in prostitution, unmarried mothers and their children, the unemployed, alcoholics and those moralized against and demonized by "respectable" Free State society, set it apart from its contemporaries. This compassion was matched by an uncompromising assault on those who claimed the moral high-ground, yet abused their status and privilege. In the pages of Honesty, the reader was confronted with the uncomfortable assertion that these "evils" were not simply the result of personal failings, but rather the result of failings of the religio-political entity that was the IFS.

Honesty was contradictory, vibrant and iconoclastic and said what other openly published journals did not dare to say, in an age of increasing censorship and intolerance of those who were perceived as betraying the nation by simply offering a counter hegemonic analysis of life in the IFS (Curtis 2010: 81). Honesty's mission was to challenge hypocrisy and injustice, a mission which Honesty declared in September 1925, informing its readers that it was against the "cant" it viewed as being endemic in the IFS (19 September 1925). Not the least of which regarding four interrelated issues of ideological as well as social importance in the IFS, namely prostitution, sexual crime, child abuse and the treatment of unmarried mothers and their children. Issues that laid down legacies that Ireland is still dealing with today.

Honesty's coverage of these issues will be demonstrated to be robust and distinct, offering a radically different analysis to that proffered by the Catholic Church (Church) and State, as well as unique in its breadth and stridency compared to other Irish mainstream journalism of the day. Upton's championing of the cause of marginalized women in his journalism was a natural extension of his politics. A committed lifetime socialist republican he had a longstanding commitment to women's rights and had amongst other things been active in the women's suffrage movement in his native Waterford from the 1910s (Lane 2010: 60). Honesty's coverage of immorality and vice ran counter to the mainstream press strategy of either ignoring socially difficult issues or reporting them on the premise that when they occurred, they resulted from the moral and intellectual inferiority of the transgressors; thereby neutralizing their existence with a motif of otherness (Ferguson 2007: 134). This distinction provided a 'cordon sanitaire' between those, contaminated by foreign vices, whose immorality had the potential to bring down the fledgling state (Crowley and Kitchin 2008: $367)$, and the "real Irish" whose virtue ensured the future of the nation.

\section{Prostitution: Not just a foreign vice of the corrupted poor}

The first of Honesty's great crusades was to expose the realities of prostitution in the IFS. Honesty was not unique in covering the issue of prostitution; it was, however, unique in its willingness to expose it to the full light of day in a way that was far less judgemental of, and punitive towards, the women engaged in the trade, irrespective of their age or background. Maria Luddy has asserted that there is ample evidence of widespread concern and discussion 
of issues relating to sexuality in Ireland in the 1920s, citing official reports and newspaper stories of trials as evidence of these discussions (2007: 194). However, it is suggested here that whilst Luddy is correct, in so far, as there was widespread evidence of concern over these issues, the reality was that the discussions based on this evidence were far from widespread, as it was not available to the general populace through the routes that she suggests. They remained instead the preserve of politicians, clerics and civil servants, many of whom did not want to expose these issues to public scrutiny as they feared its impact on both domestic morale and the IFS's international standing.

As Luddy acknowledges, the official reports were largely kept from public scrutiny. The censorship of these reports resulted from the fact that they contained information that was viewed as too toxic for public dissemination by both the State and the leadership of the Church; the Committees on Venereal Disease and the Committee to Review The Criminal Law Amendment Act 1885 (The Carrigan Committee) are two cases in point (Finnane 2001: 535). Crowley and Kitchin have asserted that this policy was designed to "ensure that unwanted discourses and threats to the national narrative were suppressed and statistics concealed, under the pretext that revelations of high levels of immorality and sexual crime" would, "offend the sensibilities of the Irish people" and "rejoice its enemies" (2008: 367).

It is the case that the clergy made regular pronouncements on sexual immorality, particularly against modern women (Beaumont 1997: 566) and the young (Luddy 2007: 199). However, the energy put into suppressing the detail, or rather the reality of these "social evils" for fear of contaminating their rather innocent and easily led flock was at least equal to the tenacity with which they pursued the dire warnings of the consequences of going against Church teaching (Keating 2012). Indeed, the Church was so concerned about the potential for this material to act as a social poison, that as soon as the IFS was established it began to actively lobby for the introduction of censorship of news material that related to sexual immorality, a goal ultimately achieved in the 1929 Censorship of Publications Act.

As a result of Church concerns, journalistic coverage was more nuanced than Luddy suggests. There had been a longstanding reticence to publish material with sexual content in the Irish press before the establishment of the IFS, due to what Inglis has referred to as a continuance of Victorian puritanism within Ireland (Inglis 2005: 5). One notable exception to this traditional reticence was the outspoken assault on child sex abuse in the Irish Worker ${ }^{5}$ in the pre-war years; however, the reticence amongst the Irish press became further entrenched with the establishment of the IFS. Admittedly, The Freeman's Journal had launched a shortlived "Crusade Against Vice", in 1923. This focused on the entrapment of young country girls by unscrupulous landlords who forced them into prostitution to pay their rent, and on the exploitation of "respectable" young girls and boys by men seeking sexual encounters. However, this campaign was devoid of any wider socio-economic analysis.

The only form of "vice" that did gain some regular level of coverage in the nation's press was that of consensual homosexual sexual encounters, which appears to have been the acceptable form of vice reporting in Ireland's national newspapers, albeit still limited. Indeed, all of the reports cited by Luddy as evidence of the reporting of sexual crime relate to convictions of men engaged in consensual same-sex acts; none referred to rape or child sex abuse. In reality the few cases of rape or child sexual abuse that ever reached court went largely unreported, and those that were reported were often covered in such an obtuse way as to mask the seriousness of the offence, even to the point of omitting the sexual nature of an assault.

The coverage of vice that made it into print atomised the issue to that of individual "evil" and was devoid of the wider context of poverty, patriarchy, class or wider religious and societal hypocrisy. The predominant focus of this reporting was on the immorality of the 
women involved and to a lesser degree the men who availed of their services, men portrayed as degenerates or dupes who fell for the charms of these dangerous and wily women.

\section{Prostitution in Dublin}

There was no appetite in the IFS to shine a light on the reality that the use of prostitutes was not just the preserve of the more degenerate sectors of Irish society, or to highlight that their services were purchased by men from throughout the social spectrum, including those who professed the greatest piety and respectability; a reality that Honesty was all too willing to expose. In its first issue, Honesty published a report on prostitution in Dublin, in which its "Special Commissioner" (SC) sought to portray prostitution as an issue which touched all levels of Irish society and not only the poor, immature and degenerate (28 February 1925).

Prostitution was argued by Church and State alike to be a manifestation of a degeneracy imported into Ireland by British imperialism and one which was exclusively responsible for the spread of venereal disease, despite ample contemporary evidence that this was not the case (Howell 2003: 326; Riordan 2007: 350). This formula provided a "cordon sanitaire" between the respectable Irish and an underclass that was therefore not 'truly' Irish, contaminated by British immorality (Keating 2012: 18). Honesty was not prepared to accept such an easy and convenient set of formulas. Its initial investigation exposed the reality that the wealthy and influential, living in well-heeled parts of town, were indulging in vice every bit as much of the poor in the run down red light district of Dublin, Monto. In the wealthier sections of town SC claimed that traders were dealing in contraceptives and immoral literature and that respectable Dublin hotels and the Dublin Metropolitan Police (DMP) were turning a blind eye to their use for immoral purposes by prostitutes serving men of the "respectable classes" (28 February 1925).

Within weeks Honesty was claiming a partial victory as a result of its "exposé," asserting, "Honesty Moves The Powers That Be". However, the police raids cited as evidence of its campains success did not target the higher status sections of town focused on by SC, but focused on Monto. Honesty's claim to have triggered this raid is rather difficult to sustain as Frank Duff ${ }^{6}$ and his Legion of Mary had been actively campaigning against prostitution in the area for some time and eventually asked for police assistance in clearing out the last intransigent brothel keepers. However, more compellingly, Honesty noted that 120 men and women were arrested but that none had been charged. This fact led the journal to muse on the incompetence of the police and to bemoan the fact that as a result the guilty went unpunished. Additionally, Honesty claimed to have "reliable" evidence that the reasons that no names were published was that certain individuals of high social status had been caught in the net of the Monto raid (21 March 1925).

Honesty's assessment of the culpability of men as the prime drivers of the sex trade, and its portrayal of them as being sexually parasitic on females made vulnerable through circumstance, were at variance with popular representations of wicked, wily women taking advantage of male weakness. In general, reportage tended to follow the accepted interpretation of prostitution offered by the IFS ideo-religious elites, which portrayed women working in prostitution as Lilith-like sexual predators. For example, Frank Duff viewed prostitutes as "lying in wait to tempt men" and as girls who "go out on the streets to seek their prey" (Luddy 2007: 202).

On 18 April 1925, in the article "Souls Sacrificed To Lust. Have We A Moral Code?" SC asserted that a large number of Dublin brothel keepers were recruiting girls at or just above the age of sexual consent, 16 at the time, whom they quickly ensnared in debt, for board, lodging or payment of fines that the girls incurred through soliciting. The relationship between prostitution and poverty was a theme that appeared regularly in Honesty's coverage. 
The appallingly low wages paid to female workers, commonly known as "sweating," was pointedly referred to in Honesty as, "white slavery" and cited as the preeminent contributory factor that drove women into prostitution. This use of the term 'white slavery' is an interesting play on its common usage. The term was used by William T. Stead in his article "Maiden Tribute of Modern Babylon" in $1885^{7}$ to indicate the selling of a woman's body for sex by those who forced her into the trade and kept her there by the threat or use of force. Honesty, in referring to the impossibility for the overwhelming majority of women to make a living wage in non-sex related employment as "white slavery" refocused the causation on the economic realitity for many women in the Free State. This usage of the term shifted the focus from individual evil to a far less collectively comfortable concept that was not in step with the way that the IFS's religio-political ideologues wished the State to be portrayed, to domestic and foreign audiences. The relationship between poverty and prostitution had been made explicit in publications like The Irish Worker, and the Irish Citizen ${ }^{8}$ in the years before World War One. Writing in the Irish Citizen in 1913, Alice Abadam argued that "Sweating," 'Prostitution' and 'Venereal Disease' shared a 'discreet causal relationship"' (Luddy 2007: 165). However, with the establishment of the IFS these voices had become more muted, none more so than that of the Fourth Estate.

For example, in 1926 the Irish Times published an article decrying the slippage in standards of morality in Ireland. The article concluded: "If the police authorities and hospitals could speak freely on this subject, they might shock the national conscience" (9 February 1926). Even this rather timid reporting style was to diminish in 1929 with the prosecution of the editor of the Waterford Standard, D.C. Boyd, for contravening the 1929 Censorship of Publications Act, over a report of a court case of an alleged rape of a thirteen-year-old girl by a wealthy local businessman. Boyd's prosecution sent a clear signal to newspaper editors of the dangers of reporting on sexual crime (Keating 2012). The Boyd case ensured that there was never any need to prosecute a newspaper editor under the Act again, in no small part as a result of what Woodman described as "Censorship through anticipation" (Woodman 1985: 20).

In an April of 1925 issue, Honesty bemoaned the lack of activity by trade unions, labour bodies and the Women Workers Union in advocating for women driven into prostitution by poverty. Honesty's article led to a response in its pages on behalf of the Women Workers Union (WWU) from Helena Molony, the revolutionary and trade union leader who had founded the Domestic Workers Union in 1917. Molony disputed the fact that the WWU had not been proactive on this issue, asserting that their research had established that those most prey to prostitution were unmarried mothers, but did acknowledge that low wages and poor working conditions played a role. Quoting one young woman who asserted "I can earn a week's wages in an hour, and no bully of a boss to put up with" (2 May 1925), Molony indicated that the efforts of the WWU had ensured that legislation was forthcoming which would deal with issues like soliciting, punishment and the age of sexual consent. In fact, however, it would not arrive for a decade. Molony's reply is illustrative of the way that sensitive issues were managed in the Free State: behind closed doors. This approach is completely at variance with Honesty's, which believed in an open public discussion on the social evils of the day and the social hypocrisy that gave them room to flourish.

Evidence of Honesty's more robust approach can be found in a piece penned by "Our Reporter" in the June of 1925 issue that castigates the lauding of a deceased businessman in a national newspaper because he was thought to have left a small legacy to "Magdalene Asylums or a Society for saving fallen women" (13 June 1925). The article argued that the businessman may well have made his fortune on the back of slave wages paid to Irish women. The article went on to compare the cost of living in Dublin with the salaries paid to large numbers of women workers, demonstrating that the wages of many women were inadequate 
to meet their basic outgoings and certainly left no surplus for the women to enjoy life beyond subsistence. A good standard of living, the article asserted, was something that human beings will strive for by "fair means or foul" (13 June 1925). Additionally, it highlighted the appalling housing conditions in Dublin and the impact of poor working and living conditions on the health of poorly paid employees - all factors, the article concluded, that were forcing young women to turn to prostitution.

In an article from August 1925, "Outrageous Treatment of Women - A Bitter Reflection," SC reported that women working as prostitutes in Dublin who were brought into overnight custody for soliciting were being paid by guards (police officers) or forced into having sex with them in the cells. Honesty informed its readership that they had first been alerted to this by a "respectable" young woman who found herself in the cells on a matter unrelated to prostitution who was both offered money for sex and manhandled when she declined. When the guard realised that she was not a prostitute, he explained that "the other women did not mind"; a story that the correspondent claimed to have had verified with police insiders, including a detective from the DMP who was trying "to clean up the situation". Notwithstanding this, the article warned, "the whole system of female detention requires urgent attention and that female staff at such places should be considerably augmented" (15 August 1925). One of the most striking features of this story is the way in which it was completely ignored in the newspapers and the Dáil (the Irish Parliament).

\section{Rape and Child Sexual Abuse}

Honesty addressed the issue of the poor state of Irish law regarding the protection of women and children from sexual assaults. An issue the Government was singularly reluctant to address or even acknowledge, notwithstanding, the desire of Eoin O'Duffy, Commissioner of the Garda Síochána (the Irish national police force), to have it addressed as a matter of urgency (Finnane 200: 534). It appeared that the Government did not wish to have it acknowledged at all, refusing a recommendation from the Department of Justice that a regular statistical update be presented to Cabinet (Crowley and Kitchin 2008: 369). As Finnane has argued, "Facing up to what was going on in their own society was not something which came easily to Irelands governing elites in the decades after independence" (2001: 535).

A further indication of the perceived toxicity of this issue for the government can be seen in the State's handling of the Carrigan Committee Report of 1931, established to review the provisions of the 1885 Criminal Law Amendment Act, with a particular focus on juvenile prostitution. This provided ample evidence of child sexual abuse in the IFS. The Committees report was handled in secret, bypassing the usual debates in the Dáil, handled by a committee of experts and kept completely beyond reach of public scrutiny. This approach was driven by a desire not to provide ammunition to the enemies of the state for them to question its virtue (Finnane 2001: 535).

Predating the Carrigan Report by some six years, Honesty, on the 18 April 1925 issue, raised concerns over the wording of the 1885 Criminal Law Amendment Act, which it argued whilst offering effective legal protection from sexual abuse to children under 13, had significant weaknesses in protecting those between 13 and 16, as it had a proviso that if the defendant could show that he had "reasonable cause to believe the girl was 16 or over he should be acquitted". Additionally, the 1885 Act also stated that unless a prosecution was commenced within three months of the commission of the offence, a prosecution could not be brought. Reputational damage was such at the time that rapes or Unlawful Carnal Knowledge (statutory rape) was often not reported unless a pregnancy ensued and then often only when the pregnancy became visible. A delay that resulted from the girl's shame or ignorance over what was happening to her body often removed the possibility of a prosecution for Unlawful 
Carnal Knowledge. In April 1926 an article in Honesty, "Child Victims of Lust", claimed that there had been a marked increase in the sexual assault of children but due to a lack of publicity in these cases the public were unaware of the extent of this crime (10 April 1926). This is an assertion that has been borne out by recent scholarship (Keating 2012: 149). To counter these concerns Honesty called for a removal of the time limitation and reasonable cause defence, in line with proposed British legislation and a raising of the age of consent to 21. The Criminal Law Amendment Act was revised in 1935 following the Report of the Carrigan Committee in 1931 (Finnane 2001); however, the age of consent was only raised to seventeen.

Honesty also raised concerns over the composition of Irish juries in the article, "Are Women Debarred From Juries?" (27 August 1925). The article expressed concern that the selection criteria for jury service hurt the ability of women to get justice, particularly in relation to sexual offences. Since the political enfranchisement of women in 1922, women had been eligible for jury service; however, women could be excused from jury service more readily than their male counterparts. This was a provision which, given their time constraints and family responsibilities, many women availed themselves of, leaving a shortage of female jurors. ${ }^{9}$ Additionally, Honesty claimed to have evidence that the State was excluding those women prepared to take part from doing so. The article claimed that three women, one a housewife, the other two small business owners, had been attending court every morning for two months without being called. Eventually, frustrated by their lack of use, they decided to sit in the public gallery to observe a trial, during which they witnessed a "little girl" being forced to give evidence regarding her sexual assault to an all-male jury. Horrified at the child's ordeal, the three women wrote to the judge expressing their surprise at not being called to serve as jurors. The Judge replied that he was powerless to intervene and directed them to the State Prosecutor to provide an explanation. The women found the State Prosecutor evasive, but they ascertained from him that "it had been decided that in future no women were to be allowed to sit on juries." In addition to this statement, they were informed by a court official, who seemed to regard it as a good joke, that "the orders were in future no women or Jews were to serve on juries" (22 August 1925). Honesty rightly asserted that if this were the case, no woman could get a fair trial in Ireland as she could not have the opportunity to be tried by her peers. The article accused the Irish State of using an old British technique of "jury packing," in favour of male defendants.

\section{Unmarried Mothers, Baby Farmers and the Unprotected Child}

In an article, “Tragedy of Unmarried Mothers. Man's Inhumanity To Women", penned by SC, the pages of Honesty reveal very real care and concern for young women who found themselves pregnant out of wedlock. It acknowledged that the majority faced the trauma of dislocation from family and community and social stigmatisation, leaving these young women "friendless, homeless, without means of kindly counsel ... Imagine if you can her mental worry, and her moneyless condition" (23 May 1925).

Honesty called for the protection and care of the mother and her child by providing maternity services. Maternity provision, it argued, should not ask questions or impose conditions but should be non-judgemental and open to all married and unmarried. This restructuring of maternity services, Honesty argued, would protect the unmarried from the ridicule and ostracization that they experienced in union hospitals ${ }^{10}$ and the dangers of being delivered by "wise women" (unqualified midwives), due to the reticence of the unmarried to attend these hospitals. The article offered a positive appraisal of the illegitimate child untypical of contemporary public opinion and official policy (Crowley \& Kitchin 2008: 365), asserting: "The State should take a pride in providing for the mother and child; even when the 
latter is illegitimate, yet it is a national asset, and in due time may become a pillar of the State or a leader of men" (23 May 1925).

The article also attacked the exploitation of unmarried mothers by what it termed "crocodiles and sharks", charities and private individuals who took money from unmarried mothers to have their children cared for or adopted with little concern for the welfare of mothers or babies, a practice known as "baby farming". This, it was argued, along with the societal shame heaped on the mother, contributed to infanticide. In the case of some charities, the article asserted, mothers were forced to pay weekly amounts, payments that if the mother defaulted on the charities would revert to "bullying" or threats in their "unfailing rapacity for their financial pound of flesh". This was an era before legalised adoption in Ireland, something that did not come until 1952. Honesty urged the Government, "If the State will not assume the role of parent, at least it can do something towards legalising adoption and making it a criminal and punishable offence to offer or accept money or any other consideration for adopting a child" (23 May 1925). In another article published on 29 March 1925, "Trafficking In Flesh And Blood," which commented on a recent inquest of a "farmed" child cared for by a woman described as an "unregistered nurse", Honesty railed against the laws that facilitated this practice.

The reality of the worst aspects of "baby farming" was illustrated in a case covered in the article "A Baby Farmer Unmasked. Sidelights On A Disgraceful Industry". The report covered a prosecution of a Mrs. Sheil. Mrs. Sheil was prosecuted following the discovery of two infant children she was "caring" for, one in the charge of the Kildare Board of Guardians for which she received 5 shillings a week, and the other through a private arrangement with her mother for which Sheil received 30 shillings a month. Both children were found in an emaciated and filthy condition in an unattended back room. The child boarded out by the Kildare Guardians was in such poor condition that it was judged that she would never enjoy good health. The other child who had only been with Sheil for a few weeks had burns on her chest, bronchitis and malnutrition. Sheil was reported to have had previously three other children in her care, two of whom had died, the evidence indicated from neglect, and another who was missing. One of the most extraordinary facts was that the Relieving Officer from the Kildare Board had not inspected or raised any concerns over the treatment of a child placed with Sheil at public expense, notwithstanding the fate of her previous charges speaks volumes about the systemic indifference to the plight of "unwanted" children operant at this time (27 July 1926).

Honesty took a particular interest in the methods and administration of St Patrick's Guild, a Dublin-based Catholic "adoption" agency founded in 1910. In the article "Baby Bargaining" in May 1925, Honesty attacked the Guild for profiting from adoptions and fostering children out to foster mothers living in the worst tenements in Dublin with very high infant mortality rates. The article also attacked the guild for failing to assess prospective parents appropriately and having inadequate aftercare or follow up to ensure an adopted child's welfare (2 May 1925). It has subsequently transpired that St. Patrick's Guild was involved in the secret export of 572 children to the US for adoption from the 1940s to the 1970s, which was more than any other adoption agency. In general, Honesty portrayed much of the charitable institutions caring for children as vehicles to profit from unmarried mothers and their families, or vehicles for self-promotion and aggrandisement for those who professed to care for vulnerable children (25 April 1925).

As well as the coverage of specific cases, the generally high death rate of children in residential care in Ireland was highlighted in the pages of Honesty: poor diets, management, and physical conditions were cited as the main reasons that children were "dying like flies" whilst in the care of the Irish State (10 October 1925). Honesty called on these charities to "cast aside hypocrisy" and provide mother and baby homes which were pleasant and non- 
judgemental, that gave mother and child the chance to bond and build a life together, over the headlong rush to adoption. These charities treated the unmarried mother and unborn child as an "enemy to society", a state of affairs Honesty described as "criminal hypocrisy" that lead to infanticide - an increasing feature, it claimed, of the reality of life in the Free State (6 February 1926).

On 18 September 1926, Honesty reported on a tragic case of infanticide in which a young girl from a "respectable" family had been thrown out of her family home and given birth alone in a hotel room. Shortly after her child was born, she killed it with a blow to the head and desposed its body in a dung heap at the back of the hotel. The article criticised those who had created the conditions in which this girl had felt that the only way to rebuild her life was to kill her baby. It asserted that people who judge others for taking "one false step" whilst regarding "themselves as the backbone of their religion usurp the place of God in daring to judge the sinner" (18 September 1926).

To alleviate the financial difficulties unmarried mothers found themselves in, Honesty proposed an alignment of Free State laws with that of other countries, including Britain, to ensure that errant fathers were forced to be financially responsible for the mother and child. Beyond the obvious financial alleviation of hardship, Honesty argued that it would also share the burden of responsibility on both parties instead of unfairly stigmatising the mother. Citing the historian William Lecky, ${ }^{11}$ Upton asserted that the differential treatment of men and women for the same transgression against moral codes "forms one of the most singular anomalies in moral history" (12 September 1925). An anomaly that Honesty fought against, root and branch.

\section{Honesty's Demise}

Upton, above all, believed in social justice and democracy. For him the worth of a society was measured by its compassion, openness, freedom and equity, whether in sexual, economic or political terms. Notwithstanding his disapproval of the political settlement that brought the IFS into being, he held the view passionately that once established it should live up to the highest democratic and humanitarian standards; something he believed that it had failed spectacularly to do. He believed that it was his journalistic mission to expose this inadequacy, irrespective of the political sensitivities at large in the fledgling state. This was a mission that took on added urgency in the case of the nation's poorest and most ostracised citizens, in particular its women and children. These issues remained a central concern of Honesty until its eventual closure in 1931 and for its editor, James W. Upton, for the rest of his life (Seamus Upton 2014). In many ways only someone with his reserves of social and political capital could have sustained the campaign that he did for so long, swimming against the tide of acceptable portrayals of the IFS and the compliant culture of the nation's mainstream press.

However, even Upton could not ultimately survive the political imperatives of Ireland's emerging political powerhouse, the Fianna Fáil party; the very party with which he had seemed to share the most common cause. Honesty's demise was caused when Upton's insistence on editorial freedom clashed with the ambitions of the leadership of Fianna Fáil, who subsequently used the party machinery to deprive Honesty of a viable readership (Keating 2015: 95).

\section{Conclusion}

In Honesty's final edition James W. Upton gave himself credit for the evolution of Honesty from a "slender weekly devoted to the reformation of social evils into an organ that molded national thought." (28 February 1931) Whatever the truth of this lofty claim, Honesty, was by 
far and away the most outspoken journal publishing on social issues in the IFS. It was prepared to name the unnameable and to "out" wrongdoers in a way the mainstream Irish press had neither the appetite nor inclination to do, particularly in regard to sexual morality and the privations of the nation's most vulnerable children.

Honesty offered an uncompromising commentary on the reality of life in the IFS, in a period when an insecure and ideologically driven elite sought to impose a news narrative which praised the IFS and its people as torchbearers of a Celtic Catholic state, largely free of the sexual vices of its former colonial occupier. In pursuance of this agenda, both State and Church sought to portray any transgressions from this narrative as alien, other, born of individual degeneracy that resulted from contamination over centuries of colonization. In this regard, Honesty offered a counter-hegemonic narrative.

Honesty was far more socially radical, raucous, gutsy, messy and uncompromising than any other contemporary Irish publication. Notwithstanding this, Honesty has been lost to the history of Irish journalism. It was a journal full of contradictions; socialist republican by instinct, yet unwilling to support any party line. It advocated for the rights of women yet displayed elements of Catholic paternalism. It championed freedom of speech yet was pro literary censorship. It spoke out against imperialism and racism yet was anti-Semitic. However, it never feared to speak out for marginalised women and children; demanding understanding and social justice for them over condemnation and isolation, in an era when liberal voices championing these causes were thin on the ground in general and non-existent in IFS journalism.

\section{Notes}

1 The founder of Sinn Féin.

${ }^{2}$ A term used to describe revolutionary publications, usually of short longevity, that published below the "radar" of the governments that they opposed.

${ }^{3}$ Names including "Mia-Eow," "Red Light," "Investigator" and "Progress."

${ }^{4}$ For examples see Honesty 7 March 1925, 7 May 1925 and 27 July 1929 and 21 September 1929.

${ }^{5}$ Journal of the Irish Transport and General Workers Union.

${ }^{6}$ Francis Michael "Frank" Duff founded the Legion of Mary, a proselytising lay organisation of the Catholic Church, in 1921.

${ }^{7}$ Pall Mall Gazette. 6 July, 1885.

${ }^{8}$ Journal of the Irish Women's Franchise League.

${ }^{9}$ This shortage was to become more pronounced in 1927 when under Part II of the 1927 Jurors Act females were excluded from Jury Service unless they chose to opt in, a development which virtually eradicated women from juries.

${ }^{10}$ Union hospitals provided medical help to the poor and destitute.

${ }^{11}$ William Edward Hartpole Lecky was an Anglican priest, Irish historian and political theorist.

\section{Works Cited}

Beaumont, Caitriona. 1997. "Women, Citizenship and Catholicism in the IFS". Women's History Review, 6.4. 563-585.

Curtis, Maurice. 2010. A Challenge to Democracy: Militant Catholicism in Modern Ireland. Dublin: The History Press.

Crowley, Una and Rob Kitchin. 2008. "Producing 'Decent' Girls: Governmentality and the Moral Geographies of Sexual Conduct in Ireland (1922-1937)". Gender, Place and Culture, 15.4. 355-372. 
Ferguson, Harry. 2007. "Abused and Looked After Children as 'Moral Dirt': Child Abuse and Institutional Care in Historical Perspective”. Journal of Social Policy, 36.1. 123-139.

Lane, L. 2010. Rosamond Jacob: Third Person Singular. Dublin: UCD Press.

Finnane, Mark. 2001. "The Carrigan Committee of 1930-31 and the 'Moral Condition of the Saorstát"'. Irish Historical Studies, 32.128. 519-536.

Fitzpatrick Dean, Joan. 2001. "The Freedom Of The Theatre In The Irish Free State 19221929; Or, The Bullet Dodged". South Carolina Review, 33.2. 135-143.

Honesty. Various, 1925-1931.

Howell, Philip. 2003. "Venereal Disease and the Politics of Prostitution in the Irish Free State". Irish Historical Studies, 33.131. 320-34.

Inglis, Tom. 2005. "Origins and legacies of Irish prudery: Sexuality and Social Control in Modern Ireland". Eire-Ireland, 40.3-4. 9-37.

Irish Times. 9 February 1926.

Keating, Anthony. 2012. "Setting the Agenda for the Press: The 1929 Case Against the Waterford Standard". New Hibernia Review, 16.2. 17-32.

. 2013. "Censorship: The Cornerstone of Catholic Ireland". Journal of Church and State, published online 21 November. Doi:10.1093/jcs/cst097.

. 2015. "Killing Off The Competition Fianna Fail's 'Dublin Junta's' Attack on Honesty". Media History, 22.1. 85-100.

Keogh, Dermot. 1998. Jews in Twentieth-Century Ireland. Cork: CUP.

Luddy, Maria. 2007. Prostitution And Irish Society 1800-1940. Cambridge: CUP.

MacDermott, Eithne. 1998. Clann na Poblachta. Cork: Cork University Press.

McGee, Owen. 2015. Arthur Griffith. Kildare: Merrion Press.

Ní Bheacháin, Caoilfhionn. 2007. “The Mosquito Press': Anti-Imperialist Rhetoric in Republican Journalism, 1926-39”. Éire-Ireland, 42.1-2. 256-289. |

Novick, Ben. 2001. Conceiving Revolution: Irish Nationalist Propaganda During the First World War. Dublin: Four Courts.

Murphy, William. 2009. The G.A.A. during the Irish Revolution. The Gaelic Athletic Association 1884-2009. Ed. Mike Cronin, William Murphy and Paul Rouse. Dublin: Irish Academic Press.

O'Connor. Barbara. 2003. "Ruin and Romance: Heterosexual Discourses on Irish Popular Dance, 1920-1960". Irish Journal of Sociology, 12.2: 50-67.

Reilly, Tom. 2005. Joe Stanley: Printer to the Rising. Cork: Brandon.

Upton, Seamus. 2014. (Son of James W. Upton). Interview with the author, 25 August.

Riordan, Susannah. 2007. "Venereal Disease in the IFS: The Politics of Public Health". Irish Historical Studies, 35.139. 345-364.

Woodman, Kieran. 1985. Media Control in Ireland 1923-1983. Carbondale, IL: Southern Illinois University Press.

Received: 31 October $2016 \quad$ Revised version accepted: 12 February 2017

Anthony Keating is a Senior Lecturer in the Psychosocial Analysis of Offending Behaviour at Edge Hill University in Lancashire, UK. He completed his PhD at Dublin City University in 2002 and was awarded a Government of Ireland Post-Doctoral Research Fellowship. He has published on child welfare and maltreatment, sexual crime and censorship in Ireland; most recently in Media History and Sport in History. 